Salton, M. R. J. \& Marshall, B. (1959). J. gen. Microbiol. 21, 415-420

\title{
The Composition of the Spore Wall and the Wall of Vegetative Cells of Bacillus subtilis
}

\author{
By M. R. J. SALTON AND BETTY MARSHALL* \\ Department of Bacteriology, University of Manchester
}

\begin{abstract}
SUMMARY: The spore wall of Bacillus subtilis is composed largely of structural protein, in contrast to the peptide + amino sugar + sugar complex of the wall of vegetative cells. Alanine, glutamic acid, $\alpha \epsilon$-diaminopimelic acid, glucosamine, muramic acid, glucose, ribitol compounds and O-ester groups are the principal constituents of the vegetative cell walls. All of the compounds characteristic of the peptide + amino sugar + sugar complex have been detected in the spore wall preparations but they account only for a minor part of the spore wall. The walls of the vegetative bacteria have a high phosphorus content and contain appreciable amounts of a ribitol phosphate polymer. Spore walls and vegetative cell walls differ also in the nature of their $\mathrm{N}$-terminal amino acids; glycine is the principal $\mathrm{N}$-terminal amino acid of the spore wall protein whereas alanine is the main amino acid found in the wall of vegetative cells.
\end{abstract}

The composition of isolated spore walls or spore 'coats' of several members of the genus Bacillus was first investigated by Strange \& Dark (1956a). Apart from a qualitative study by Yoshida, Izumi, Tani, Tanaka, Takaishi, Hashimoto \& Fukui (1957) .there have been no reports defining the differences in composition of spore walls and the walls of vegetative cells of spore-forming bacteria. It was apparent from the studies of Strange \& Dark (1956a) that the spore wall with its high nitrogen content and variety of amino acids would differ from the peptide + amino sugar + sugar complexes encountered in the walls of many Gram-positive bacteria (Cummins \& Harris, 1956; Salton, 1953, 1958). The results presented in the present paper summarize some of the chemical differences between the spore wall and cell wall of a strain of Bacillus subtilis.

\section{METHODS}

Isolation of spore walls and walls of vegetative bacteria. Bacillus subtilis was grown with aeration in nutrient broth at $30^{\circ}$. For the preparation of walls of vegetative bacteria, the organisms were harvested after $16 \mathrm{hr}$. growth, washed with distilled water and disintegrated by the procedures previously described (Salton \& Horne, 1951). After sporulation of B. subtilis in the nutrient broth the spores were harvested by centrifugation and washed three times with distilled water. Spores were then crushed by shaking for $c .2 \mathrm{hr}$. with ballotini beads $\left(c .0 \cdot 13 \mathrm{~mm}\right.$. diameter) on a reciprocating shaker at $0^{\circ}$. The spore walls were washed with distilled water on the centrifuge. Ultraviolet absorption spectra of the spore-wall preparations did not reveal any absorption maxima corresponding to nucleic acids or dipicolinic acid (Powell, 1953) although

* Present address: Division of Food Preservation and Transport, Commonwealth Scientific and Industrial Research Organization, Homebush, N.S.W., Australia. 
several very small 'humps' were apparent at wavelengths of $c .240$ and $280 \mathrm{~m} \mu$. Digestion of the spore walls with trypsin eliminated the substances responsible for the ultraviolet absorption. For all experiments reported below, spore walls and cell walls were digested with trypsin (1 mg. trypsin/ml.; 0.1 Mphosphate buffer, $\mathrm{pH} 8 ; 2 \mathrm{hr}$. at $37^{\circ}$ ) before analysis.

\section{Chemical analyses}

Nitrogen. The nitrogen content was determined on triplicate samples by the procedure described by Johnson (1941) after digestion as in the Kjeldahl method.

Phosphorus was estimated colorimetrically by the Fiske \& SubbaRow (1925) procedure.

Amino sugars were determined by the colorimetric method of Rondle \& Morgan (1955) after hydrolysis of the wall preparations in sealed ampoules with $2 \mathrm{~N}-\mathrm{HCl}$ for $2 \mathrm{hr}$. at $100^{\circ}$. For the individual estimation of glucosamine and muramic acid, the hydrolysates were applied to Whatman paper $3 \mathrm{MM}$ and separation of the basic glucosamine from the neutral muramic acid was achieved by electrophoresis (12 volts/cm., $2 \mathrm{hr}$., $0.05 \mathrm{M}$-ammonium acetate buffer, pH 6.3). Muramic acid was eluted from the 'neutral' zone and glucosamine from the 'basic' zone of the electrophoresis paper. Both amino sugars were then estimated by the method of Rondle \& Morgan (1955), with glucosamine hydrochloride as the standard. Expressing the muramic acid as glucosamine equivalents underestimates the quantity of this amino sugar in the preparations. Strange \& Dark (1956b) showed, with crystalline muramic acid, that its colour yield under the conditions of the amino sugar colour reaction is less than that of glucosamine. In the absence of a standard of muramic acid, the glucosamine equivalent at wavelength $530 \mathrm{~m} \mu$ was multiplied by a factor of 1.78 (Strange \& Dark, 1956 b) to give the muramic acid contents.

Lipid contents were determined by extraction with ether or by ether extraction after hydrolysis of the walls with $6 \mathrm{~N}-\mathrm{HCl}$ as previously described (Salton, 1953).

O-ester groups were estimated quantitatively by the method of Hestrin (1949); the results are expressed for comparative purposes as $\mathbf{O}$-acetyl contents although the nature of the O-ester groups has not been established.

Diaminopimelic acid (DAP) contents were determined on hydrolysed wall preparations by the colorimetric procedure of Work (1957).

Identification of wall constituents by paper chromatography. Amino acids and amino sugars were identified after two-dimensional paper chromatographic separation (Whatman paper No. 1, pyridine+water, 4:1, v/v; $n$-butanol + glacial acetic acid + water, $6: 1: 2 \mathrm{v} / \mathrm{v}$ ) of the $6 \mathrm{~N}-\mathrm{HCl}$ hydrolysates $\left(16 \mathrm{hr}\right.$. at $\left.107^{\circ}\right)$. For estimating the relative molecular proportions of the amino acids, the chromatograms were dipped in a solution of ninhydrin $(5 \%, w / v$ in acetone + phosphate buffer $[9.5 ; 0.5$ by volume]) and the colours were eluted with a mixture of acetone and water $(3: 1, v / v)$ and the extinctions determined at wavelength $570 \mathrm{~m} \mu$. 
Wall constituents possessing free amino groups were identified by reacting the preparations with 1-fluoro-2:4-dinitrobenzene (FDNB) and determining the nature of the dinitrophenyl (DNP) derivatives by paper chromatography and paper electrophoresis of the products liberated by $6 \mathrm{~N}-\mathrm{HCl}$ hydrolysis as described by Ingram \& Salton (1957).

Detection of ribitol compounds. The presence of ribitol phosphate compounds in our cell-wall (but not in the spore-wall) preparations was reported by Baddiley, Buchanan \& Carss (1958). With the detection of muramic acid and DAP in the spore-wall preparations it was necessary to examine the sporewall preparations again, using the Buchanan, Dekker \& Long (1950) spray for the detection of polyols. Spore wall $(30 \mathrm{mg}$.) was hydrolysed with $2 \mathrm{~N}-\mathrm{HCl}$ for $3 \mathrm{hr}$. at $100^{\circ}$, after removal of the $\mathrm{HCl}$ by evaporation in vacuo over conc. $\mathrm{H}_{2} \mathrm{SO}_{4}$ and $\mathrm{NaOH}$ pellets, the products were taken up in distilled water and applied to Whatman paper No. 1 as a band $(5 \mathrm{~cm}$. wide). The papers were irrigated with $n$-butanol + glacial acetic acid + water $(3: 1: 1, \mathrm{v} / \mathrm{v})$ and the dried papers treated as described by Buchanan et al. (1950).

Sugar constituents were identified with the aniline phthalate spray reagent on paper chromatograms of hydrolysates of wall preparations $\left(0.5 \mathrm{~N}-\mathrm{H}_{2} \mathrm{SO}_{4}\right.$, $16 \mathrm{hr}$. at $100^{\circ}$; followed by neutralization with $\mathrm{Ba}(\mathrm{OH})_{2}$ and de-ionizing with a mixed resin bed of Amberlite IR $120(\mathrm{H})+\mathrm{IR} 4 \mathrm{~B}(\mathrm{OH})$ ). Paper chromatographic separation was achieved on Whatman paper No. 1, using ethyl acetate + pyridine + water (Jermyn \& Isherwood, 1949) as the solvent system.

Lysozyme sensitivity was determined as described by Salton (1956).

\section{RESULTS}

The results of the quantitative analysis of the spore walls and the walls of vegetative Bacillus subtilis are presented in Table 1. The nature of the major cell-wall and spore-wall constituents identified in acid hydrolysates

Table 1. Analysis of spore walls and roalls of vegetative Bacillus subtilis

\begin{tabular}{|c|c|c|}
\hline \multirow[b]{2}{*}{ Total N } & \multicolumn{2}{|c|}{$\begin{array}{c}\text { Spore walls Cell walls } \\
\text { Dry weight }(\%)\end{array}$} \\
\hline & $12 \cdot 9$ & $4 \cdot 6$ \\
\hline Total P & $1 \cdot 4$ & $4 \cdot 2$ \\
\hline $\begin{array}{l}\text { Total amino sugars } \\
\text { (as glucosamine) }\end{array}$ & $\mathbf{2 \cdot 2}$ & $10 \cdot 7$ \\
\hline Glucosamine & $1 \cdot 5$ & $7 \cdot 9$ \\
\hline Muramic acid & $0.6(1.1)^{*}$ & $2 \cdot 8(4 \cdot 1)^{*}$ \\
\hline $\begin{array}{l}\text { Diaminopimelic acid } \\
\text { Lipid }\end{array}$ & c. 1 & $5 \cdot 6$ \\
\hline a. ether extractable & $1 \cdot 4$ & 0.2 \\
\hline b. total $\uparrow$ & $\mathbf{3 \cdot 0}$ & 0.7 \\
\hline $\begin{array}{l}\text { O-ester groups (as } \\
\text { O-acetyl) }\end{array}$ & 0.027 & $0 \cdot 255$ \\
\hline
\end{tabular}

* Values in brackets represent muramic acid contents corrected by the factor of $1 \cdot 78$ (Strange \& Dark, 1956b).

$\dagger$ 'Total lipid' estimated by ether extraction after hydrolysis according to Salton (1953). 
together with the identification of compounds possessing free amino groups are summarized in Table 2.

Digestion of the walls of vegetative $B$. subtilis with lysozyme liberated $93 \%$ of the weight of the walls as soluble components, leaving behind an insoluble wall residue accounting for $7 \%$ of the original wall material.

\section{DISCUSSION}

The results of the analysis of the spore walls of Bacillus subtilis reported above are in close agreement with those obtained by Strange \& Dark (1956a). Although the spore-wall preparations contain the components characteristic of the peptide + amino sugar complex of the wall of vegetative organisms, these constituents represent only a minor part of the spore wall. It seems unlikely that these components arise from contamination with vegetative walls, since glucose, a constituent of the latter, was not detectable in the spore-wall preparations. Strange \& Dark (1956a) also observed the presence of the 'spore peptides' in the spore-coat fractions of other Bacillus species.

\section{Table 2. A comparison of some of the products identified in acid hydrolysates} of walls of spores and of vegetative cells of Bacillus subtilis

\section{Spore walls}

(lysine (6); glycine (5); serine (4); alanine (4); glutamic acid (3); valine/methionine (2); leucine/ isoleucine (2); tyrosine (1.5); aspartic acid (1); DAP (1); threonine (1); arginine, cystine, histidine, proline and phenylalanine present in smaller amounts.

Amino sugars glucosamine, muramic acid

Sugars

Products of reaction with FDNB Ribitol compounds $†$
$\{$ none detectable in $30 \mathrm{mg}$. hydro$\{$ lysed wall

$\{$ DNP-glycine; trace DNP. $\{$ alanine; mono DNP-DAP (1)*

$\{$ Small amounts detectable in

$\left\{\begin{array}{c}30 \mathrm{mg} \text {. hydrolysed wall } \\ \text {. }\end{array}\right.$

\section{Cell walls}

alanine (4); glutamic acid (2); DAP (1); traces of aspartic acid, serine, valine and leucine.

\author{
glucosamine, muramic \\ acid \\ glucose \\ DNP-alanine; \\ mono DNP-DAP (5)* \\ Readily detectable in \\ $5 \mathrm{mg}$. hydrolysed wall
}

* Relative proportions of mono DNP-DAP in the preparations.

$\uparrow$ Detectable mainly as the anhydro-ribitol compound.

The marked difference between the phosphorus contents of spore walls and of vegetative cell walls can be accounted for by the ribitol phosphate polymer as a major wall component of the vegetative cells (Baddiley et al. 1958). However, the spore wall contained $1.4 \% \mathrm{P}$ and the results of the paper chromatographic detection of ribitol compounds gave the impression that there was more phosphorus than could be accounted for by the small amounts of the ribitol phosphate polymer found. It is evident therefore that the spore wall contained phosphorus compounds other than the ribitol phosphate polymer (the teichoic acids of Armstrong, Baddiley, Buchanan, Carss \& Greenberg, 
1958) and lipids. Yoshida et al. (1957) observed a small difference between the P-content of the walls of spores and of vegetative cells of Bacillus cereus. The presence of $\mathrm{O}$-acetyl groups in bacterial cell walls was first reported by Abrams (1958). Armstrong et al. (1958) found alanine as an O-ester group in the techoic acids. We have not determined whether the O-ester groups of the spore and cell-wall preparations are exclusively $\mathbf{O}$-alanyl groups or whether there are also O-acetyl groups.

The amount of lipid that we found in the walls of Bacillus subtilis is comparatively low; it agrees with the data of Strange \& Dark (1956a). However, a lipid content of $3 \%$ could readily account for the hydrophobic properties of bacterial spores if the lipid were oriented on the outer surface of the spore wall.

We wish to thank Dr W. G. Murrell for the preparation of the spore walls. One of us (B.M.) was indebted to the Commonwealth Scientific and Industrial Research Organization of Australia for a maintenance grant.

\section{REFERENCES}

Aвrams, A. (1958). O-Acetyl groups in the cell wall of Streptococcus faecalis. J. biol. Chem. $230,949$.

Armstrong, J. J., Baddiley, J., Buchanan, J. G., Carss, B. \& Greenberg, G. R. (1958). Isolation and structure of ribitol phosphate derivatives (teichoic acids) from bacterial cell walls. J. chem. Soc. p. 4344.

Baddiuex, J., Buchanan, J. G. \& Carss, B. (1958). The presence of ribitol phosphate in bacterial cell walls. Biochim. biophys. Acta, 27, 220.

Buchanan, J. G., Dekrer, C. A. \& Long, A. G. (1950). The detection of glycosides and non-reducing carbohydrate derivatives in paper partition chromatography. J. chem. Soc. p. 3162.

Cummins, C. S. \& Harris, H. (1956). The chemical composition of the cell wall in some Gram-positive bacteria and its possible value as a taxonomic character. J. gen. Microbiol. 14, 583.

Fiske, C. E. \& SubbaRow, Y. (1925). The colorimetric determination of phosphorus. J. biol. Chem. 66, 375.

Hestrin, S. (1949). The reaction of acetylcholine and other carboxylic acid derivatives with hydroxylamine, and its analytical application. J. biol. Chem. 180, 249.

Ingram, V. M. \& Salton, M. R. J. (1957). The action of fluorodinitrobenzene on bacterial cell walls. Biochim. biophys. Acta, 24, 9.

JERMYN, M. A. \& IsHerwood, F. A. (1949). Improved separation of sugars on the paper partition chromatogram. Biochem. J. 44, 402.

Jornson, M. J. (1941). Isolation and properties of a pure yeast polypeptidase. J. biol. Chem. 137, 575.

PowelL, J. E. (1953). Isolation of dipicolinic acid (pyridine-2:6-dicarboxylic acid) from spores of Bacillus megatherium. Biochem. J. 54, 210.

Rondle, C. J. M. \& MorgaN, W. T. J. (1955). The determination of glucosamine and galactosamine. Biochem. J. 61, 586.

Salton, M. R. J. (1953). The composition of the cell walls of some Gram-positive and Gram-negative bacteria. Biochim. biophys. Acta, 10, 512.

Salton, M. R. J. (1956). The action of lysozyme on cell walls of some lysozyme sensitive bacteria. Biochim. biophys. Acta, 22, 495.

Salton, M. R. J. (1958). The lysis of micro-organisms by lysozyme and related enzymes. J. gen. Microbiol. 18, 481. 
SAlton, M. R. J. \& HoRne, R. W. (1951). Methods of preparation and some properties of cell walls. Biochim. biophys. Acta, 7, 177.

Strange, R. E. \& Dark, F. A. (1956a). The composition of the spore coats of Bacillus megatherium, B. subtilis and B. cereus. Biochem. J. 62, 459.

Strange, R. E. \& Dark, F. A. (1956b). An unidentified amino-sugar present in cell walls and spores of various bacteria. Nature, Lond. 177, 186.

Work, E. (1957). Reaction of ninhydrin in acid solution with straight-chain amino acids containing two amino groups and its application to the estimation of $\alpha \epsilon$-diaminopimelic acid. Biochem. J. 67, 416.

Yoshida, N., IzUmi, Y., Tani, I., Tanaka, S., Takaishi, K., Hashimoto, T. \& FukU, K. (1957). Studies on the chemical composition of bacterial cell walls and spore membranes. J. Bact. 74, 94.

(Received 6 April 1959) 